ISSN 0258-7122

Bangladesh J. Agril. Res. 39(3): 419-426, September 2014

\title{
GENETIC VARIABILITY OF YIELD AND ITS CONTRIBUTING CHARACTERS ON CIMMYT MAIZE INBREDS UNDER DROUGHT STRESS
}

\author{
MD. GOLAM AZAM ${ }^{1}$, UMAKANTA SARKER ${ }^{2}$ \\ MANIRUZZAM $^{3}$ AND BHAGYA RANI BANIK ${ }^{4}$
}

\begin{abstract}
This experiment was conducted in a randomized block design with three replications at Bangladesh Agricultural Research Institute, Gazipur-1701 during the rabi season of 2010 with 25 maize inbred lines. Correlation and path coefficient analysis were done for yield and some other traits. Genotypic variations were observed for ear height and grains/row. The highest broad sense heritability $\left(\mathrm{h}_{\mathrm{b}}^{2}\right)$ was observed for yield/plant followed by ear height and 1000grain weight. Maximum genetic advance in percentage of mean (GA) was recorded for yield/plant (92.652) and ear height (75.87). The yield/plant showed significant positive genotypic correlation $\left(\mathrm{r}_{\mathrm{g}}\right)$ with cob diameter $(0.440)$ and grains/row (0.265). Significant negative correlation was observed between ear height and yield and also for days to 50\% tasseling. The highest direct positive effect was obtained for rows/cob. These studies suggest that cob diameter, row per cob, grains/row and ear height were the most important yield contributing factors and an attempt should, therefore, be made for an effective selection of these traits.
\end{abstract}

Keywords: Maize (Zea mays L.), variability, correlation, path analysis, Bangladesh.

\section{Introduction}

Maize (Zea mays L.) is the third leading important cereal crop after rice and wheat. Hybrid varieties of maize have been commercially exploited in different cereal loading countries of the world because it has a greater genetic potentiality compared to synthetic and composite varieties. The area and production of maize is increasing day by day in Bangladesh and it continues to expand rapidly at an average rate of $20 \%$ per year (BBS 2008).

Hybrid varieties are also becoming popular among the maize growers in Bangladesh. At present, some NGOs and seed companies have imported hybrid maize seed and distributed to the maize growing farmers.

\footnotetext{
${ }^{1}$ Scientific Officer, Bangladesh Agricultural Research Institute (BARI), Jessore; ${ }^{2}$ Associate Professor, Department of Genetics and Plant Breeding Bangabandhu Sheikh Mujibur Rahman Agricultural University (BSMRAU), Gazipur; ${ }^{3}$ Senior Scientific Officer, Plant Breeding Division, BARI, Gazipur; ${ }^{4}$ Director, Spice Research Center, BARI, Bogra, Bangladesh.
} 
Bangladesh faces a serious problem of water shortage for crop production. The water resources are becoming limiting and it has been estimated that water for irrigation purposes may be reduced. Abiotic stresses limit maize productivity (Bahl et al., 1977 and Mohammadia et al., 2003). Among various abiotic stresses, drought is undoubtedly one of the most terrible natural enemy in plant lifecycle. Western part of Bangladesh is drought prone and called Barendra area.

But an understanding of genetic basis of drought tolerance in crop plants based on various morpho-physiological traits is also a pre-requisite for a geneticist to evolve superior genotype through either conventional breeding methodology or genetic engineering (Falconer, 1989 and Singh, 1978). It is, therefore, effective maize breeding programme would be launched to evolve high yielding and well adapted hybrids/varieties for water deficit conditions. Inbred lines are prerequisite in the production of commercial hybrid varieties of maize. So, a study of genetic variability in inbred lines is essential before designing an efficient hybridization programme aiming to develop high yielding hybrid varieties. Seed or grain yield is a complex character, which is affected by a large number of yield contributing characters. For this reason, careful selection of desirable individual may lead to discover lines with higher yield than the original variety. Coefficient measures the degree and strength of relationship between the yield and other yield contributing characters which is helpful for selection of desirable characters under a breeding programme (Falconer, 1989). The measurement correlation of coefficient between the characters is matter of considerable importance in selection practices which help in the construction of selection indicates and also permit the prediction of correlated response (Lerner, 1985). Many workers have reported wide area of work about correlation coefficient (Sandhu et al., 1972; Bahl et al., 1977; Khoskhoi and Niknesad, 1972; Islam et al., 1984; Shahi et al., 1984).

The estimates of path coefficient analysis are important for better understanding of the crop. It gives specific measures of direct and indirect effect of each component character under seed yield (Singh and Singh, 1974). Therefore, present study was undertaken to find out selection for identifying parents for hybridization programme in order to develop hybrid varieties through the study of heritability, genetic variability and relationship between yield and yield components traits in maize inbred lines.

\section{Materials and Method}

The experiment consisting of 25 inbred maize genotypes received from CIMMYT, India. The experiment was conducted at Bangladesh Agricultural Research Institute (BARI), Gazipur during rabi 2010-2011. The inbred lines were grown in a randomized complete block design with three replications. The 
seeds of each inbred lines were sown in a single row of $5 \mathrm{~m}$ long plot. Spacing adopted was $75 \mathrm{~cm} \times 20 \mathrm{~cm}$ between rows and hills, respectively. One healthy seedling/hill was kept after proper thinning. Fertilizers were applied @ 120, 80, $80,20,5$, and $1 \mathrm{~kg} / \mathrm{ha}$ of $\mathrm{N}, \mathrm{P}_{2} \mathrm{O}_{5}, \mathrm{~K}_{2} \mathrm{O}, \mathrm{S}, \mathrm{Zn}$, and $\mathrm{B}$, respectively. Standard agronomic practices were followed (Quayyum, 1993) and plant protection measures were taken when required. No irrigation was given during experimental period. Data on days to 50\% tasseling and silking were recorded on whole plot basis. Ten randomly selected plants were used for recording ten characters viz., days to 50\% silking (DS), days to 50\% tasseling (DT), plant height $(\mathrm{PH})$, ear height (EH), cob length (CL), cob diameter (CD), rows/cob $(\mathrm{R} / \mathrm{C})$, grains/row $(\mathrm{G} / \mathrm{R}), 1000$-grain weight $(\mathrm{GW})$, and grain yield/plant $(\mathrm{Y} / \mathrm{P})$. Genotypic and phenotypic coefficients of variation were estimated as per Singh and Chaudhary (1979). The broad sense heritability and genetic advance in percentage of mean were calculated as suggested by Jonson et al. (1955). Genotypic and phenotypic correlation coefficients were calculated according Miller et al. (1958). Path coefficient analysis was estimated according to method suggested by Dewey and Lu (1959).

\section{Results and Discussion}

The estimates of $\sigma^{2} g, \sigma^{2} p$, genotypic (GCV) and phenotypic coefficient of variation $(\mathrm{PCV}), \mathrm{h}_{\mathrm{b}}^{2}, \mathrm{CV}$ and genetic advance in percentage of mean (GA) for different characters have been presented in Table 1. The highest $\sigma^{2} g$ and $\sigma^{2} p$ were found for yield/plant (639.28 and 639.65) and 1000-grain weight (217.27 and 217.74). This is in line with the previous results of Mutisya (1987). Lowest amount of $\sigma^{2} \mathrm{~g}$ and $\sigma^{2} \mathrm{p}$ was observed in cob diameter (1.043 and 1.703).

The GCV and PCV were the highest for yield/plant followed by ear height and grains/row. High GCV for grain yield and 1000-grain weight were also observed in maize (Malhotra and Khehra, 1986). High GCV and PCV for grain yield/plant, ear height and grains/row indicated that selection of these traits would be effective. Days to $50 \%$ silking and days to $50 \%$ tasseling had moderate $\mathrm{h}^{2}{ }_{\mathrm{b}}$ but low GCV; therefore, there is a limited scope of selection. Park et al. (1990) in an earlier study with maize reported similar results.

The heritability $\left(\mathrm{h}_{\mathrm{b}}^{2}\right)$ ranged from 61.250 to 99.942 . High heritability was observed for grain yield/plant (99.942) followed by 1000-grain weight (99.784) and ear height (98.796) which suggested that selection for improvement of these characters would be effective through phenotypic selection. High heritability estimates is indicating to preponderance of additive gene action. In the present study, high GA with high $\mathrm{h}_{\mathrm{b}}^{2}$ was observed for yield/plant, ear height, grains/row Higher genetic advance for grain yield/plant, ear height, plant height, and grains/row depicts additive gene effects. 
In addition, the lowest CV was determined for 1000 -grain weight as $0.83 \%$, the highest CV was determined for the rows/cob (7.48\%). Similar results were obtained by previous researches of Burhan (2007).

Table 1. Estimation of genetic parameters of variation for ten characters of the 25 maize genotypes.

\begin{tabular}{c|l|l|l|l|l|l|l|l}
\hline Characters & $\begin{array}{c}\text { Grand } \\
\text { mean }\end{array}$ & $\sigma^{2} \mathrm{~g}$ & $\sigma^{2} \mathrm{p}$ & $\begin{array}{l}\mathrm{GCV} \\
(\%)\end{array}$ & $\begin{array}{l}\mathrm{PCV} \\
(\%)\end{array}$ & $\mathrm{h}_{\mathrm{b}}^{2}(\%)$ & $\mathrm{GA}$ & $\mathrm{CV} \%$ \\
\hline DT & 94.48 & 18.544 & 21.691 & 4.558 & 4.929 & 85.493 & 8.682 & 1.88 \\
DS & 97.39 & 21.630 & 25.203 & 4.776 & 5.155 & 85.822 & 9.114 & 1.94 \\
EH & 30.63 & 128.774 & 130.344 & 37.054 & 37.279 & 98.796 & 75.870 & 4.09 \\
PH & 91.90 & 363.457 & 370.211 & 20.745 & 20.937 & 98.176 & 42.343 & 2.83 \\
CL & 10.10 & 5.512 & 5.883 & 23.241 & 24.012 & 93.686 & 46.340 & 6.03 \\
CD & 11.28 & 1.043 & 1.703 & 9.056 & 11.572 & 61.250 & 14.601 & 7.20 \\
R/C & 11.60 & 2.304 & 3.058 & 13.087 & 15.075 & 75.363 & 23.403 & 7.48 \\
G/R & 16.46 & 18.004 & 19.115 & 25.782 & 26.566 & 94.187 & 51.545 & 6.40 \\
GW & 261.99 & 217.661 & 217.359 & 17.792 & 17.811 & 99.784 & 36.611 & 0.83 \\
Y/P & 177.72 & 639.897 & 639.586 & 44.990 & 45.003 & 99.942 & 92.652 & 1.08 \\
\hline
\end{tabular}

Legend: Days to $50 \%$ silking $=\mathrm{DS}$, Days to $50 \%$ tasseling $=$ DT, Plant height=PH, Ear height $=\mathrm{EH}$, Cob length $=\mathrm{CL}, \mathrm{Cob}$ diameter $=\mathrm{CD}$, rows $/ \mathrm{cob}=\mathrm{R} / \mathrm{C}$, grains $/$ row $=$ $\mathrm{G} / \mathrm{R}, 1000$-grain weight $=\mathrm{GW}$ and Grain yield $/$ plant $=\mathrm{Y} / \mathrm{P}$

The $r_{g}$ and $r_{p}$ between all possible combinations of ten characters are presented in Table 2. In general, it was observed that $r_{G}$ were higher in magnitude than $r_{p}$ and in the same direction. Grain yield/plant showed genetically significant positive correlation with cob diameter $(0.440)$, grains/row $(0.265)$, and negatively significant correlation with plant height $(0.175)$ and days to $50 \%$ tasseling (0.115 ). Rest of characters should positively and negatively non-significant corelation with grain yield. Similar associations were also reported by Parh et al. (1986) and Khanday and Thakur (1990) and Singh et al. (1995).

Among the pair of characters, the days to $50 \%$ tasseling was the significantly positive correlated with days to $50 \%$ silking (0.992), cob length (0.487), grains/row (0.477) but negatively and significantly correlated with 1000-grain weight (-0.500) and yield/plant (-0.115). Debnath (1987), however, observed positive correlation of ear length with ear diameter and number of kernels/row. Days to $50 \%$ silking was significantly and positively correlated with cob length (0.992), cob length (0.482), grains/row (0.447) but negatively and significantly correlated with 1000-grain weight (-0.461). Ear height showed no significant 
correlation with other characters except plant height (0.751). Plant height was positively significant with cob length $(0.0 .427)$ and 1000 -grain weight $(0.176)$ but negatively and significantly correlated with rows/cob (0.509), grain yield/plant (-0.175). Cob length was positively significant only in the character grains/row (0.743) but negatively and significantly correlated with rows/cob (0.509) and grain yield/plant (-0.175). Cob diameter was significantly positive correlated with rows/cob (0.817), grain yield/plant (0.440) but no negative correlation between the characters. Rows/cob were positively significant with grains/row (0.449) but negatively and significantly correlated with 1000-grain weight $(0.433)$. Grains/row were the significantly and positively correlated with grain yield/plant $(0.265)$ but negatively and significantly correlated with 1000 grain weight (0.487).

From the above discussion, we can show that cob diameter has the maximum contribution for increasing yield followed by grains/row. The learning propose of the experiment that selection on the basis of cob diameter and grains/row may bring out desired improvement towards the grain yield.

Table 2. Genotypic $\left(r_{g}\right)$ and Phenotypic $\left(r_{p}\right)$ correlations among grain yield and yield different contributing characters in maize genotypes.

\begin{tabular}{|c|c|c|c|c|c|c|c|c|c|c|}
\hline \multicolumn{2}{|c|}{ Characters } & DS & $\mathrm{PH}$ & EH & $\mathrm{CL}$ & $\mathrm{CD}$ & $\mathrm{R} / \mathrm{C}$ & $\mathrm{G} / \mathrm{R}$ & GW & $\mathrm{Y} / \mathrm{P}$ \\
\hline \multirow[t]{2}{*}{ DT } & $r_{g}$ & 1.034 & -0.080 & -0.029 & $0.487 *$ & 0.045 & 0.326 & $0.477 *$ & $-0.500^{*}$ & $-0.115^{*}$ \\
\hline & $\mathrm{r}_{\mathrm{p}}$ & $0.923 * *$ & -0.075 & -0.013 & $0.446^{*}$ & 0.055 & 0.283 & $0.439 *$ & $-0.464 *$ & $-0.105^{*}$ \\
\hline \multirow[t]{2}{*}{ DS } & $r_{g}$ & & -0.059 & -0.015 & $0.482^{*}$ & 0.029 & 0.314 & $0.447 *$ & $-0.461^{*}$ & -0.139 \\
\hline & $r_{p}$ & & -0.054 & -0.008 & $0.436^{*}$ & 0.005 & 0.213 & 0.393 & $-0.428 *$ & -0.129 \\
\hline \multirow[t]{2}{*}{ EH } & $r_{g}$ & & & $0.751 * *$ & 0.356 & 0.114 & -0.313 & 0.209 & 0.165 & -0.113 \\
\hline & $r_{p}$ & & & $0.744 * *$ & 0.345 & 0.103 & -0.273 & 0.204 & 0.164 & -0.112 \\
\hline \multirow[t]{2}{*}{$\mathrm{PH}$} & $r_{g}$ & & & & $0.427 *$ & -0150 & $-0.509 * *$ & 0.173 & $0.176^{*}$ & $-0.175^{*}$ \\
\hline & $r_{p}$ & & & & $0.414^{*}$ & -0.111 & $-0.428^{*}$ & 0.171 & 0.173 & -0.173 \\
\hline \multirow[t]{2}{*}{$\mathrm{CL}$} & $r_{g}$ & & & & & 0.140 & 0.197 & $0.743 * *$ & -0.215 & -0.071 \\
\hline & $r_{p}$ & & & & & 0.102 & 0.147 & $0.710^{* *}$ & -0.206 & -0.069 \\
\hline \multirow[t]{2}{*}{$\mathrm{CD}$} & $r_{g}$ & & & & & & $0.817^{* *}$ & 0.327 & -0.109 & $0.440^{*}$ \\
\hline & $r_{p}$ & & & & & & $0.509 * *$ & 0.266 & -0.012 & $0.346^{*}$ \\
\hline \multirow[t]{2}{*}{$\mathrm{R} / \mathrm{C}$} & $r_{g}$ & & & & & & & $0.449 *$ & $-0.433^{*}$ & 0.309 \\
\hline & $r_{p}$ & & & & & & & 0.374 & -0.377 & 0.272 \\
\hline \multirow[t]{2}{*}{$\mathrm{G} / \mathrm{R}$} & $r_{g}$ & & & & & & & & $-0.487 *$ & $0.265^{*}$ \\
\hline & $\mathrm{r}_{\mathrm{p}}$ & & & & & & & & $-0.469^{*}$ & $0.256^{*}$ \\
\hline \multirow[t]{2}{*}{$\mathrm{GW}$} & $r_{g}$ & & & & & & & & & -0.039 \\
\hline & $r_{p}$ & & & & & & & & & -0.039 \\
\hline
\end{tabular}

*: significant at 0.05 level, **: significant at 0.01 level 
The path coefficient analysis (Table 3) revealed that most of the traits had positive direct effect on grain yield. The highest direct effect on grain yield was exhibited by rows/cob followed by days to $50 \%$ silking and plant height. Ear diameter had highest indirect effect on grain yield through grain rows followed by days to $50 \%$ tassel through rows/cob and days to $50 \%$ silking through rows/cob. Similar results in maize have earlier been reported by El-Shouny et al., (2005), Mohammadia et al., (2003) and Rafiq et al.,(2010).

Table 3. Path coefficient analysis of genotypic correlation showing direct (bold) and indirect effects of yield contributing characters towards yield in maize genotypes.

\begin{tabular}{c|l|l|l|l|l|l|l|l|l|l}
\hline Characters & DT & DS & EH & PH & CL & CD & R/C & G/R & G/W & \multicolumn{2}{l}{$\begin{array}{l}\text { Correlation } \\
\text { With grain } \\
\text { yield }\end{array}$} \\
\hline DT & $\mathbf{- 0 . 4 3 1}$ & 7.139 & -0.428 & -0.194 & -3.953 & -0.879 & 8.193 & 1.125 & -3.746 & $-0.1149^{*}$ \\
DS & -8.391 & $\mathbf{0 . 5 4 1}$ & -0.315 & -0.101 & -3.907 & -0.560 & 7.899 & 1.055 & -3.454 & -0.139 \\
EH & 0.652 & -0.409 & $\mathbf{0 . 4 8 3}$ & 5.028 & -2.892 & -2.216 & -7.876 & 0.493 & 1.240 & -0.113 \\
PH & 0.235 & -0.104 & 3.998 & $\mathbf{0 . 5 3 4}$ & -3.468 & 2.910 & -12.820 & 0.409 & 1.318 & $-0.175^{*}$ \\
CL & -3.953 & 3.324 & 1.898 & 2.862 & $\mathbf{- 0 . 4 2 2}$ & -2.705 & 4.951 & 1.753 & -1.609 & -0.071 \\
CD & -0.368 & 0.200 & 0.610 & -1.007 & -1.134 & $\mathbf{- 0 . 8 4 3}$ & 20.572 & 0.772 & -0.064 & $0.440^{*}$ \\
R/C & -2.641 & 2.167 & -1.666 & -3.411 & -1.596 & -15.820 & $\mathbf{- 0 . 8 6 2}$ & 1.059 & -3.248 & 0.309 \\
G/R & -3.869 & 3.085 & 1.113 & 1.161 & -6.026 & -6.332 & 11.293 & $\mathbf{0 . 2 3 1}$ & -3.650 & $0.265^{*}$ \\
GW & 4.053 & -3.179 & 0.881 & 1.177 & 1.741 & 0.165 & -10.901 & -1.148 & $\mathbf{0 . 6 9 3}$ & -0.039 \\
\hline
\end{tabular}

*: significant at 0.05 level, **: significant at 0.01 level

Residual effect, $\mathbf{R}=0.392$

Legend: Days to $50 \%$ silking $=\mathrm{DS}$, Days to $50 \%$ tasseling $=$ DT, Plant height=PH, Ear height $=\mathrm{EH}$, Cob length $=\mathrm{CL}$, Cob diameter $=\mathrm{CD}$, rows $/ \mathrm{cob}=\mathrm{R} / \mathrm{C}$, grains/row $=\mathrm{G} / \mathrm{R}, 1000$-grain weight $=\mathrm{GW}$ and Grain yield $/$ plant $=\mathrm{Y} / \mathrm{P}$

Correlation and path coefficient analysis showed that cob diameter and grains/row were the important yield components in maize. Grains/row and ear height also showed high GCV, heritability coupled with high genetic advance. Therefore, the result revealed that grains/row and ear height were important yield contributing traits for hybridization programme based on these traits.

\section{References}

Bahl, P.N. and U.K. Jain. 1977. Association among agronomic characters and plant ideotype in chickpea. Zeitschrift fur. Flanzen Fuchtung 79 (2): 154-159.

BBS. 2008. Year Book of Agricultural Statistics in Bangladesh. Bangladesh Bureau of Statistics, Ministry of Planning. Govt. of the People's Republic of Bangladesh, Dhaka. 
Burhan, A. 2007. Relationship among yield and some yield characters in potato. J. Biol. Sci. 7: 973-976.

Debnath, S. C. 1987. Genetic variability in maize (Zea mays L.). Bangladesh J. Agric. 12(4): 217-221.

El-Shouny, K.A., O.H.El-Baguory, K.I.M.Ibrahim and S.A.Al-Ahmad. 2005. Correlation and path coefficient analysis in four yellow maize crosses under two planting dates. Arab-Univ. J.Agri.Sci. 13 (2):327-339.

Falconer, D. S. 1989. Introduction to quantitative genetics. 3rd Ed. English Language Book Society/ Longman.

Islam, M.G., K Begum and A.K. Kaul. 1984. Phenotypic variability and correlation studies in Kabuli chickpea. Bangladesh J. Agric. Res. 9 (1): 33-37.

Johnson, H. W., H. F. Robinson and R. E. Comstock.1955. Estimates of genetic and environmental variability in soybean. Agron. J. 47(7): 314-318.

Khanday, B. A and R. C. Thakur. 1990. Correlation of yield components in rainfed maize (Zea mays). Indian J. Agric. Sci. 60(12): 830-831.

Khoskhui, M. and M. Niknesad. 1972. Plant height and width inheritance and their correlations with some of the yield components in chickpea. J. Agric. Sci. 578: 37-38.

Lerner, M. 1985. The genetic basis of selection. John Willey and Sons, New York, P. 122.

Malhotra, V.V. and A.S. Khehra. 1986. Genotypic variation and covariation in indigenous germplasm of maize. Indian J. Agric. Sci. 56: 811-816.

Miller, P. A., C. Williams, H. F. Robinson and R. E. Comstock. 1958. Estimates of genotypic and environmental variance and covariance and their implication in selection. Agron. J. 50: 126-131.

Mohammadia, S.A., B. M. Prasanna and N.N. Singh. 2003. Sequential path model for determining interrelationship among grain yield and related characters in maize. Crop Sci. 43: 1690-1697.

Parh. D. K... M. A. Hossam and M J. Uddin. 1986. Correlation and path coefficient analysis in open pollinated maize (Zea mays). Bangladesh J. Agric. 11(1): 11-14.

Park O.K., M.K, Kabir, S.A. Hossain and MA Khaleque. 1990. Evaluation of efficiencies of the selection indices of yield in open-pollinated maize. Bangladesh J. Pl. Breed. Genet. 3 (1\&2): 9-14.

Quayyum, M.A. 1993. Bhuttar Chash Paddhati (in Bengali). In: Chowdhury, M.K. and M.A. Islam (ed.). Bhuttar Utpadan O Babohar. Bangladesh Agricultural Research Institute, Gazipur, Pp. 43-48.

Rafiq M., M. Rafique, A. Hussain and M. Altaf. 2010. Studies on heritability, correlation and path analysis in maize (Zea mays L.). J. Agric. Res. 2010, 48(1)

Shahi, V.K., Singh, N.B., Chowdhury V.K., Ojha, C.B. and S.K. Chowdhury. 1984. Yield components and their application in breeding bengal gram. Indian J. Agric. Res. 18 (3): 155-157. 
Singh, D. 1978. Correlation studies in gram (Cicer arieiinwn L.). Labdev J. Set. Tech. 6(3): 155-158.

Singh, D.D. and D. Singh. 1974. Correlation in indian Cozla Brassica campestris L., var. Sarson prain. Indian J. Agric. Sci. 44(3) 142-144.

Singh. G. M. Singh and K. R. Dhiman. 1995. Genetic analysis of maize (Zea mays) in Sikkim. Indian J. Agric. Sci. 65(4): 293-294.

Singh., R. K and B. D. Chaudhary. 1979. Biometrical methods in quantitative genetic analysis. Kalyani Publications. New Delhi. 